\title{
VALIDATING A THEORY OF PLANNED BEHA VIOR QUESTIONNAIRE TO MEASURE ENTREPRENEURIAL INTENTIONS
}

\author{
Samuel Rueda \\ Assistant Professor, Dept. Social Psychology, University of Seville \\ srueda@us.es
}

Juan Antonio Moriano

Associate Professor, Dept. Social Psychology, National Distant-Learning University

(UNED, Madrid)

jamoriano@psi.uned.es

\section{Francisco Liñán}

Associate Professor, Dept. Applied Economics, University of Seville

$\underline{\text { flinan@us.es }}$

\section{Acknowledgements}

This study it is part of the VIE Project (Cultural Values and Socioeconomic Factors as determinants of the Entrepreneurial Intention), which has been financed by the regional government of Andalusia (Department of Innovation, Science and Enterprise; Reference Number: P08-SEJ-03542).

We are also grateful to the universities collaborating in the data gathering (a complete list of them is published at the project web-page: http://institucional.us.es/vie). 


\title{
VALIDATING A THEORY OF PLANNED BEHAVIOR QUESTIONNAIRE TO MEASURE ENTREPRENEURIAL INTENTIONS
}

\begin{abstract}
The Theory of Planned Behavior (TPB, Ajzen, 1991) has been widely employed to predict entrepreneurial intentions. The TPB offers a coherent and generally applicable theoretical framework, which enables us to understand and predict entrepreneurial intentions by taking into account not only personal but also social factors (Krueger et al., 2000). This study presents the validation of an Entrepreneurial Intention Questionnaire (EIQ) in a sample of more than three thousand Spanish university graduates. The EIQ comprises four subscales: attitudes towards entrepreneurship, subjective norms, self-efficacy, and entrepreneurial intention. Unlike other questionnaires used in the field (Autio, Keeley, Klofsten, Parker \& Hay, 2001; Krueger, Reilly \& Carsrud, 2000; Liñán \& Chen, 2009), EIQ follows Ajzen's (Ajzen, 2002) methodological recommendations on how to construct a TPB questionnaire using composite measures of attitudes and subjective norms. Structural equation modeling (SEM) confirmed that the EIQ has a high reliability and predictive validity for Spanish university graduates' entrepreneurial intentions.
\end{abstract}

Keywords: Entrepreneurship; intention; questionnaire validation; attitudes; self-efficacy

\section{INTRODUCTION}

The decision to become an entrepreneur is a deliberate and conscious decision (Krueger, et al., 2000). Creating a new company requires time, involving both considerable planning and a high degree of cognitive processing (Baron, 2004). Thus, an entrepreneurial career decision can be considered the type of planned behavior for which intention models are ideally suited (Bird, 1988). Entrepreneurial intentions, in turn, are a deciding factor for performing entrepreneurial behavior (Kolvereid \& Isaksen, 2006).

This research embraces the Theory of Planned Behavior (TPB) developed by Ajzen (1991), which takes into account personal and social factors to explain intentional behaviors. The TPB is an important socio-cognitive theory that has been successfully applied in a wide variety of fields (e.g. Beck \& Ajzen, 1991; Harland, Staats \& Wilke, 1999). It explains entrepreneurial intentions in a more detailed and consistent way than alternative models (Krueger, et al., 2000; van Gelderen, et al., 2008). The TPB integrates two lines of research on entrepreneurial intentions: research on the relationships between attitudes and entrepreneurial intention (Douglas \& Shepherd, 2002), and research on the connections between self-efficacy and entrepreneurial intention (Jung, Ehrlich, DeNoble \& Baik, 2001). The TPB has been used successfully in the past to describe entrepreneurial intentions of students in the U.S. (Autio, et al., 2001; Krueger, et al., 2000), The Netherlands (van 
Gelderen, et al., 2008), Norway (Kolvereid, 1996), Russia (Tkachev \& Kolvereid, 1999), Finland, Sweden (Autio, et al., 2001), Germany (Jacob \& Richter, 2005), Spain and Taiwan (Liñán \& Chen, 2009; Moriano, 2005), and South Africa (Gird \& Bagraim, 2008).

However, as Autio et al. (2001) have noted, the measurement of individual entrepreneurial intent has been characterized by disparate metrics, and no rigorously-developed and psychometrically-validated measurement scale has so far been developed (Thompson, 2009). A good part of these differences may have been due to measurement issues (Chandler \& Lyon, 2001). In fact, measuring cognitive variables implies considerable difficulty (Baron, 1998). Thus, empirical tests have differed widely. Krueger et al. (2000) used single-item variables to measure each construct. Kolvereid (1996) used a belief-based measure of attitudes. More recently, Kolvereid and Isaksen (2006) have used an aggregate measure for attitudes, but a single-item one for intention. Similarly, some of these studies used an unconditional measure of intention (Autio, et al., 2001; Kickul \& Zaper, 2000; Kolvereid \& Isaksen, 2006; Krueger, et al., 2000; Zhao, Siebert \& Hills, 2005), while others forced participants to state their preferences and estimated likelihoods of pursuing a selfemployment career "as opposed to organizational employment" (Erikson, 1999; Fayolle, Gailly \& Lassas-Clerc, 2006; Kolvereid, 1996). Besides, as Thompson (2009) explains, several different multi-item measures have in fact been used in past research alluding to entrepreneurial intent. Mueller and Thomas (2001), for instance, use a combination of Rotter's (1966) external-internal locus of control and Jackson's (1994) innovativeness scales. Schmitt-Rodermund and Vondracek (2002) use a scale based on three subscales adapted from Holland's (1985) vocational interests, skills, and behavioral measures. Reitan (1997) reports using a 21-item scale, Chen et al. (1998) report using a 5-item measure, and Vesalainen and Pihkala (1999) report using three different continuous measures of entrepreneurial intent, one a single item and two multi-item scales. More recently, Audet (2004) uses a 2-item scale and Thompson (2009) uses a 6-item scale based in four categories: intentions or plans to start a firm, learning about starting a firm, looking for business opportunities, and active behaviors to gathering initial resources to start a firm.

Therefore, there is work to be done to produce a standard measurement instrument for entrepreneurial intention and its antecedents. In this sense, this article develops an Entrepreneurial Intention Questionnaire (EIQ), based on an integration of psychology and entrepreneurship literature, as well as previous empirical research in this field. The EIQ tries to overcome the main shortcomings of previous research instruments while, at the same time, following strictly the recommendations by Ajzen (2002). The thus produced instrument will allow a more theoretically and psychometrically sound measurement of the entrepreneurial intention and its antecedents.

\section{THEORY OF PLANNED BEHAVIOR (TPB) EXPLAINING ENTREPRENEURIAL INTENTIONS}

Intentionality as well as forethought are acknowledged to be core features of human beings (Bandura, 2001). Intention constitutes a representation of the direction of future action. It affects individuals' choices as well as directs and maintains behavior. Research to date in areas as diverse as health-related behavior, voting behavior, spare-time activity, or job seeking demonstrates that intention is a strong predictor of behavior (see Armitage \& Conner, 


\section{1 for a review).}

Entrepreneurial intention is defined as the conscious state of mind that precedes action and directs attention towards a goal such as starting a new business (Bird, 1988; Krueger \& Carsrud, 1993). Forming an intention to develop an entrepreneurial career is the first step in the often-long process of venture creation (Gartner, Shaver, Gatewood \& Katz, 1994). Several models aim to explain entrepreneurial intentions such as the Shapero's Entrepreneurial Event Model (Shapero \& Sokol, 1982), the Model of Implementing Entrepreneurial Ideas (Bird, 1988) or Maximization of the Expected Utility (Douglas \& Shepherd, 2002). Although these models represent a step forward in entrepreneurial behavior research, they have not been as influential as the TPB (Autio et al., 2001; Krueger et al., 2000; van Gelderen et al., 2008; Tkachev \& Kolvereid, 1999). Unlike other models, the TPB offers a coherent and generally applicable theoretical framework, which enables us to understand and predict entrepreneurial intention by taking into account not only personal but also social factors (Krueger et al., 2000). As such, personal history and characteristics and skills can predispose individuals towards entrepreneurial intentions, as well as the social context (social support and culture). However, according to the TPB, only the three TPB components - attitude towards behavior, subjective norms, and perceived behavioral control predict behavioral intentions directly. All other factors are theorized to influence intentions indirectly, through these three components.

The attitude towards behavior within the TPB is defined as an individual's overall evaluation of a behavior (Ajzen, 1991). Previous studies on the subject of entrepreneurial intention have measured attitudes by using only one item, which focuses on the personal interest in starting a business (Autio et al., 2001; Krueger et al., 2000). However, single-item measures are prone to measurement unreliability (DeVellis, 1991). According to the TPB, the attitude toward a behavior is determined by the total set of accessible behavioral beliefs linking the behavior to various outcomes and other attributes. In addition, the strength of each belief is weighted by the evaluation of the outcomes (Ajzen, 1991). Thus, two people may hold an equally strong belief that entrepreneurship involves facing new challenges, but one of them may view these challenges positively while the other may consider them unpleasant. This two-element process of attitude formation allows us to explain why persons holding different beliefs may exhibit identical attitudes, and vice versa.

The second component of the TPB is the subjective norm, which is defined as the individual's perception of the social pressures to engage (or not to engage) in entrepreneurial behavior (Ajzen, 1991). The subjective norm consists of two components: normative beliefs and the motivation to comply with these beliefs (Ajzen \& Fishbein, 1980). Normative beliefs concern the perceived probability that important referent individuals or groups will approve or reject a given behavior; they set the norm that specifies how the subject should behave. The second component, motivation to comply, reflects a person's willingness to conform to these norms, i.e. to behave in keeping with the expectation of important referents. Depending on the social environment, these pressures can become a trigger or a barrier to the development of an entrepreneurial career.

The third TPB component, perceived behavioral control (PBC), refers to people's perceptions of their ability to perform a given behavior. Individuals usually choose to perform behaviors that they think they will be able to control and master. This concept is therefore very similar to self-efficacy (or even the same, see Bandura, 1982). Both concepts concerned the perceived ability to perform a behavior, e.g., starting a new business. In their review of TPB, Armitage and Conner (2001) conclude that self-efficacy is more clearly 
defined and more strongly correlated with intentions than PBC. In fact, self-efficacy has replaced PBC in numerous studies (Krueger et al., 2000; Kolvereid \& Isaksen, 2006; Moriano, 2005; van Gelderen et al., 2008), and a recent meta-analysis showed that it is strongly positively related to business creation and entrepreneurial success (Rauch \& Frese, 2007).

The intention to perform a given behavior constitutes the central element of TPB (Ajzen, 1991): the stronger the intention to perform a given behavior, the greater the probability of its effective performance. Reviews of existing research show that intention accounts for approximately $30 \%$ of the variance in behavior (Armitage \& Conner, 2001). Furthermore, past research shows that the individual TPB components (attitude, subjective norms, PBC) in turn together explain between 21\% (Autio et al., 2001) and 55\% (Liñán \& Chen, 2009) of the variance in the intention to develop an entrepreneurial career. However, the strength of their influence on intention varies from study to study.

This research, therefore, aims at establishing the psychometric properties of the EIQ (item and construct reliabilities, convergent and discriminant validities). At the same time, it also aims at establishing the predictive validity of the EIQ by testing the following hypotheses:

Hypothesis 1: The attitude toward entrepreneurship will have a positive effect on the entrepreneurial intention.

Hypothesis 2: The subjective norms will have a positive effect on the entrepreneurial intention.

Hypothesis 3: The entrepreneurial self-efficacy will have a positive effect on the entrepreneurial intention.

Insert Figure 1 here

METHOD

\section{Sample}

Participants in this study are 3223 Spanish university graduates (mean age 28.08; $S D=$ 4.98) from 15 different universities in Spain ${ }^{1}$. Table 1 shows some of the main sample characteristics.

Insert Table 1 here

\footnotetext{
${ }^{1}$ The complete list of collaborating universities is included in the Project web-page: http://institucional.us.es/vie
} 


\section{Procedure}

Participation in the study was voluntary. All questionnaires were completed anonymously to ensure confidentiality. Questionnaires were completed over the Internet, as part of the development of the VIE Project (http://institucional.us.es/vie/es/index.php). The VIE project attempts to assess the influence of personal and cultural values, together with socioeconomic variables, in the formation of entrepreneurial attitudes and intentions.

All 74 universities in Spain have been contacted, asking them to distribute the information about the project and the questionnaire to their alumni. Collaboration was obtained from 15 of them. Data collection stretched from February to October 2010.

\section{Measurement Instruments}

The TPB questionnaire comprises four subscales: attitudes towards entrepreneurship, subjective norms, PBC, and entrepreneurial intention. Unlike other questionnaires used in the field (Autio et al., 2001; Krueger et al., 2000; Liñán \& Chen, 2009), EIQ follows Ajzen's (2002) methodological recommendations of how to construct a TPB questionnaire using composite measures of attitudes and subjective norms. All items in the questionnaire were measured on a 7-point Likert Scale (from 0 to 6). The EIQ instrument is available from the authors upon request.

Attitudes towards entrepreneurship were measured with two sets of six items that assess expected outcomes of an entrepreneurial career as well as desirability of these outcomes. Following Ajzen (2002), outcome expectations were multiplied by their desirability and then divided by six to obtain scale average scores, with higher scores reflecting more positive attitudes towards an entrepreneurial career.

Subjective norms were measured with two sets consisting of three items each measuring how significant others (e.g. parents) would view their entrepreneurial career choice as well as their motivation to comply with these reference people. These two sets were multiplied and then divided by three to obtain average scale scores. Higher scores are reflective of more positive subjective norms.

The EIQ measures $P B C$ through entrepreneurial self-efficacy in line with other research on entrepreneurial intentions (Krueger et al., 2000; Kolvereid \& Isaksen, 2006; Moriano, 2005; van Gelderen et al., 2008). In this study, we used a six-item entrepreneurial selfefficacy scale. High scores indicate high entrepreneurial self-efficacy.

Entrepreneurial intention was measured using a four-item scale in which each item assesses the perceived likelihood of an individual to choose an entrepreneurial career. Higher scores reflect stronger entrepreneurial intentions.

\section{RESULTS}

Structural equation modelling (SEM) was used to test the validity and the reliability of 
each scale included in the questionnaire. SEM is a statistical methodology that takes a hypothesis testing (i.e., confirmatory) approach to the multivariate analysis of a structural theory bearing on some phenomenon (Byrne, 2001). Further, SEM is an especially appropriate method for analysing the inter-relationships in a model (Hair, Black, Babin, Anderson \& Tatham, 2006).

\section{Measurement model}

The measurement model is based on the relationships between the manifest variables (indicators) and the hypothesized latent constructs. The model proposed involved 19 manifest indicators (measures) loading onto 4 latent constructs (see Table 2). A confirmatory factor analysis (CFA) was carried out to assess reliability and validity of the scales used in this research.

Measure reliability. Firstly, the individual reliability of each indicator is given by loading or correlations between the indicator and the construct $(\lambda)$. Researchers postulate that a latent variable should explain a substantial part of each indicator's variance (usually at least 50\%). Accordingly, the standardized outer loadings should be higher than .60 (Hair, et al., 2006). After running the first analysis, items A2 ("To create employment for other people") and A4 ("To have a high income") obtained low loadings ( $\lambda=.56$ and $\lambda=.50$, respectively) on to the attitude scale. Item A4 was removed from the model and the analysis was run again. As a result, item A2 increased its loading up to .58, very close to the cutoff value (.60); therefore we decided to keep this item in the final measurement model.

Secondly, the scale reliability allows measuring internal consistency of all indicators in relation with the construct. The composite reliability $\left(\rho_{c}\right)$ is a preferred alternative to Cronbach's $\alpha$ as a measure of internal consistency reliability. While Cronbach's $\alpha$ assumes that all indicators are equally reliable, $\rho_{\mathrm{c}}$ prioritizes indicators according to their reliability, resulting in a more reliable composite (Henseler, Ringle \& Sinkovics, 2009 ). The acceptable cutoff for $\rho_{\mathrm{c}}$ would be the same as the researcher sets for Cronbach's $\alpha$ since both attempt to measure internal consistency reliability. Consequently, $\rho_{c}$ value should be above .70 , whereas a value below .60 indicates a lack of reliability (Nunnally, 1978). Table 2 shows the results of the measurement model and indicates that the constructs of attitude toward entrepreneurship, subjective norm, entrepreneurial self-efficacy, and entrepreneurial intention exceeded the minimum requirements.

Insert Table 2 Here

Convergent and discriminant validity. The convergent validity represents the common variance between the indicators and their construct, and it means that a set of indicators are measuring the same underlying construct (Henseler, et al., 2009 ). Fornell and Larcker (1981) recommend using the average variance extracted (AVE) as a criterion. The higher the AVE value, the more representative the indicators are of the construct on which they load. In general, Its value should be above .50 (Fornell \& Larcker, 1981). As shown in Table 2, the AVE for each construct was satisfactory. To assess discriminant validity among constructs, 
the AVE square root should be higher than the squared correlation with all other constructs (Fornell \& Larcker, 1981). Therefore, each construct should share more variance with its own block of indicators than with another construct representing a different block of indicators (Henseler, et al., 2009 ). Table 3 shows the correlations between the constructs and, along the diagonal, the AVE square roots. In view of this data, there is discriminant validity among the constructs assessed, although all variables are significant and positively correlated, which is in line with previous studies (Douglas \& Shepherd, 2002; Kolvereid, 1996; Kolvereid \& Isaksen, 2006; Krueger \& Carsrud, 1993; Krueger, et al., 2000; Liñán \& Chen, 2009; Liñán, Urbano \& Guerrero, 2011; Tkachev \& Kolvereid, 1999; van Gelderen, et al., 2008).

Insert Table 3 Here

\section{Structural model}

We tested our hypotheses by estimating the model shown in Figure 1. The analyses were carried out using the matrix of the original data as input and the maximum likelihood procedure. The goodness-of-fit of the models was evaluated using the chi-square $\left(\chi^{2}\right)$ statistic. Low chi-square values, with insignificant levels $>.05$ or .01 , provide evidence that there are no statistically significant differences between the actual and predicted input matrices. Due to the sensitivity of the $\chi^{2}$ statistic to sample size and the deviations from normality of the data, other absolute and incremental fit indices were proposed. The Normed Fit Index (NFI) and the Comparative Fit Index (CFI) are relative fit-indices for which, as a rule of thumb, values greater than .90 are considered as indicating a good fit (Byrne, 2001). In addition, the Root Mean Square Error of Approximation (RMSEA) is computed for which values lower than .07 indicate a reasonable fit of the model (Hu \& Bentler, 1995).

The model fit was satisfactory. Although the $\chi^{2}$ was significant $(\chi 2(126)=1587.46, p<$ .01 ), the RMSEA of .06 indicated an acceptable fit, and the NFI and the CFI were also above the commonly recommended level $(\mathrm{NFI}=.95, \mathrm{CFI}=.96)$. As shown in Figure 2 , the entrepreneurial self-efficacy had the greatest effect on the entrepreneurial intention $(\beta=.44, p$ $<.01$ ), whereas the subjective norms had the lowest impact on the entrepreneurial intention $(\beta=.08, p<.01)$. These findings are in line with previous research that has pointed out the weak role of the subjective norms to predict the entrepreneurial intention (Autio, et al., 2001; Krueger, et al., 2000; Liñán \& Chen, 2009; Liñán, et al., 2011). Overall, the TPB factors were able to explain a high percentage of the entrepreneurial intention's variance $\left(R^{2}=.46\right)$, which is a significant indication of the predictive validity of the TPB questionnaire.

Insert Figure 2 Here

\section{DISCUSSION}

The TPB is widely used and accepted in entrepreneurship research. In general, results strongly support its validity in explaining the entrepreneurial intention of individuals. The 
research questions should no longer be whether TPB is applicable, but more subtle and refined ones: are there any differences in the values of the parameters between diverse groups of individuals? Are there additional variables that should be considered, at least for some specific populations? Are there any socio-cultural variables that may mediate the effect of motivational antecedents on entrepreneurial intentions? In which way?

However, and precisely to answer these questions, a reliable and valid measure that may be confidently used in this field was clearly lacking. We truly believe the EIQ could be such a measure. Using a standard instrument may be very useful to assess the similarities and differences in the intention-formation process between different groups of individuals. The EIQ has a strong theoretical basis and has also exhibited sound psychometric properties.

Similarly, some authors are recently calling for more evolved entrepreneurial intention models (Krueger, 2009). It has been argued that subjective norms may partly explain attitude and self-efficacy (Liñán \& Chen, 2009; Liñán, et al., 2011). Likewise, the possibility that some interaction effects may be present between some of the motivational antecedents of intention (Fitzsimmons \& Douglas, 2011) deserves further investigation. In this sense, the use of SEM analysis on different samples to compare both structural models (basic TPB model and modified model) should be needed. The EIQ renders these comparisons possible, offering a guarantee of comparable and trustworthy results.

The EIQ has been tested on a large sample of university graduates. This is an important difference with regard to other previous instruments that were used on student samples. The use of students, although very accessible, is subject to criticism (Robinson, Stimpson, Huefner \& Hunt, 1991). It is argued that it is a very special group of the population with little real experience and limited responsibilities. It may, therefore, not be representative of the general adult population. In contrast, university graduates tend to enter the labor market just after graduation, and assume responsibilities at work relatively sooner than other less educated groups. Besides, people with university education in the 25-34 age-group are especially inclined towards entrepreneurship (Bosma, Acs, Autio, Coduras \& Levie, 2008). In Spain, $24.8 \%$ of this age group (25-34 years) has university education (2001 census data). Therefore, our sample is representative of a large and significant population segment.

\section{Limitations and suggestions for future research}

This paper represents an ambitious attempt to validate a research instrument with methodological rigor and a wide and carefully selected sample. However, this sample is limited to university graduates. Although, as mentioned above, this group is especially relevant in entrepreneurship, may not be fully representative of the whole adult population. Therefore, further research should be carried out that would serve both to confirm the EIQ validity, and also to analyze differences in the intention-formation process between subgroups of the population.

During the validation process, item A4 did not fulfill item-reliability conditions. This situation deserves closer attention. The attitude scale is based on salient beliefs about what is like to be an entrepreneur, and how desirable these outcomes are for the individual. People may have different beliefs about entrepreneurship. Therefore, the different items in the scale need not be highly correlated. At least theoretically, the attitude scale could present a 
formative character, instead of being reflective in nature (Diamantopoulos \& Winklhofer, 2001). This possibility should be considered and tested in subsequent research.

\section{Practical implications}

Once the EIQ has been validated and starts to be used in comparative research, it will shed light on the specific details involved in the intention-formation process (parameters, interactions, mediation effects ...). In particular, comparisons between different groups of the population and cross-national and cross-cultural comparisons may now be made. Results from this and future research will help explain in which ways personality, demographics, culture or institutions affect the way people perceive entrepreneurship. Based on these results, better and more focused interventions may be devised. And thus policy action may become more effective.

\section{References}

Ajzen, I. (1991). The Theory of Planned Behavior. Organizational Behavior and Human Decision Processes, 50(2), 179-211.

Ajzen, I. (2002). Constructing a TPB questionnaire: conceptual and methodological considerations Retrieved Noviembre 2006, from http://www.people.umass.edu/aizen/

Ajzen, I., \& Fishbein, M. (1980). Understanding attitudes and predicting social behavior. Englewood Cliffs, NJ: Prentice-Hall.

Armitage, C. J., \& Conner, M. (2001). Efficacy of the theory of planned behavior: a metaanalytic review. British Journal of Social Psychology, 40(4), 471-499.

Audet, J. (2004). A longitudinal study of the entrepreneurial intentions of university students. Academy of Entrepreneurship Journal, 10(1), 3-16.

Autio, E., Keeley, R. H., Klofsten, M., Parker, G. G. C., \& Hay, M. (2001). Entrepreneurial intent among students in Scandinavia and in the USA. Enterprise and Innovation Management Studies, 2(2), 145-160.

Bandura, A. (1982). Self- Efficacy Mechanism in Human Agency. American Psychologist, $37,122-147$.

Bandura, A. (2001). Social cognitive theory: an agentic perspective. Annual Review of Psychology, 52(1), 1-26.

Baron, R. A. (1998). Cognitive mechanisms in entrepreneurship: Why and when entrepreneurs think differently than other people. Journal of Business Venturing, 13(4), 275-294.

Baron, R. A. (2004). The cognitive perspective: a valuable tool for answering entrepreneurship's basic "why" questions. Journal of Business Venturing, 19(2), 221239.

Beck, L., \& Ajzen, I. (1991). Predicting Dishonest Actions Using the Theory of Planned Behavior. Journal of Research in Personality, 25(3), 285-301.

Bird, B. (1988). Implementing entrepreneurial ideas: the case for intention. Academy of Management Review, 13(3), 442-453.

Bosma, N., Acs, Z. J., Autio, E., Coduras, A., \& Levie, J. (2008). Global Entrepreneurship Monitor. 2008 executive report. Wellesley, Massachusetts and London: Global Entrepreneurship Research Consortium (GERA). 
Byrne, B. M. (2001). Structural equation modeling with AMOS, EQS, and LISREL. International Journal of Testing, 1(1), 55-86.

Chandler, G. N., \& Lyon, D. W. (2001). Issues of Research Design and Construct Measurement in Entrepreneurship Research: The Past Decade. Entrepreneurship Theory and Practice, 25(4), 101-113.

Chen, C. C., Greene, P. G., \& Crick, A. (1998). Does entrepreneurial self-efficacy distinguish entrepreneurs from managers? Journal of Business Venturing, 13(4), 295-316.

DeVellis, R. F. (1991). Scale development: theory and applications. Newbury Park, CA: Sage.

Diamantopoulos, A., \& Winklhofer, H. M. (2001). Index construction with formative indicators: An alternative to scale development. Journal of Marketing Research, 38, 269-277.

Douglas, E. J., \& Shepherd, D. A. (2002). Self-Employment as a Career Choice: Attitudes, Entrepreneurial Intentions, and Utility Maximization. Entrepreneurship Theory and Practice, 26(3), 81-90.

Erikson, T. (1999). A study of entrepreneurial career choices among MBAs - The extended Bird model. Journal of Enterprising Culture, 7(1), 1-17.

Fayolle, A., Gailly, B., \& Lassas-Clerc, N. (2006). Assessing the impact of entrepreneurship education programmes: a new methodology. Journal of European Industrial Training, 30(9), 701-720.

Fitzsimmons, J. R., \& Douglas, E. J. (2011). Interaction between feasibility and desirability in the formation of entrepreneurial intentions. Journal of Business Venturing, 26(4), 431-440. doi: 10.1016/j.jbusvent.2010.01.001

Fornell, C., \& Larcker, D. F. (1981). Evaluating Structural Equation Models with Unobservable Variables and Measurement Error: Algebra and Statistics. Journal of Marketing Research, 18(3), 39-50.

Gartner, W. B., Shaver, K. G., Gatewood, E. J., \& Katz, J. A. (1994). Finding the entrepreneur in entrepreneurship. Entrepreneurship Theory and Practice, 18(3), 5-10.

Gird, A., \& Bagraim, J. J. (2008). The theory of planned behavior as predictor of entrepreneurial intent amongst final-year university students. South African Journal of Psychology, 38(4), 711-724.

Hair, J. F., Black, W. C., Babin, B. J., Anderson, R. E., \& Tatham, R. L. (2006). Multivariate Data Analysis (6 ed.). New Jersey: Pearson

Harland, P., Staats, H., \& Wilke, H. (1999). Explaining proenvironmetal intention and behavior by personal norms and the theory of planned behavior. Journal of Applied Social Psychology, 29(2), 505-528.

Henseler, J., Ringle, C. M., \& Sinkovics, R. R. (2009 ). The use of partial least squares path modeling in international marketing. Advances in International Marketing 20, 277319 doi: $10.1108 /$ S1474-7979

Holland, J. L. (1985). Making vocational choices. A theory on vocational personalities and work environments. Englewood Cliffs, NJ: Prentice-Hall.

Hu, L.-T., \& Bentler, P. M. (1995). Evaluating Model Fit. In R. H. Hoyle (Ed.), Structural Equation Modeling. Concepts, issues and applications. (pp. 77-100). Londres: Sage.

Jackson, D. N. (1994). Jackson Personality Inventory-Revised Manual. Port Heron, MI: Sigma Assessment Systems, Inc.

Jacob, K., \& Richter, P. G. (2005). Absichten zur gründung eines unternehmens bei studierenden [Students' intentions to found a business]. Wirtschaftspsychologie, 2, 51-70. 
Jung, D. I., Ehrlich, S. B., DeNoble, A. F., \& Baik, K. B. (2001). Entrepreneurial SelfEfficacy and its Relationship to Entrepreneurial Actions: A Comparative Study Between the US and Korea. Management International, 6(1), 41-53.

Kickul, J., \& Zaper, J. A. (2000). Untying the knot: do personal and organizational determinants influence entrepreneurial intentions? Journal of Small Business and Entrepreneurship, 15(3), 57-77.

Kolvereid, L. (1996). Prediction of employment status choice intentions. Entrepreneurship Theory and Practice, 21(1), 47-57.

Kolvereid, L., \& Isaksen, E. (2006). New business start-up and subsequent entry into selfemployment. Journal of Business Venturing, 21(6), 866-885.

Krueger, N. F. (2009). Entrepreneurial intentions are dead: long live entrepreneurial intentions. In A. Carsrud \& M. Brannback (Eds.), Understanding the entrepreneurial mind (pp. 51-72). New York: Springer.

Krueger, N. F., \& Carsrud, A. L. (1993). Entrepreneurial intentions: applying the theory of planned behavior. Entrepreneurship and Regional Development, 5(4), 315-330.

Krueger, N. F., Reilly, M. D., \& Carsrud, A. L. (2000). Competing models of entrepreneurial intentions. Journal of Business Venturing, 15(5-6), 411-432.

Liñán, F., \& Chen, Y. W. (2009). Development and cross-cultural application of a specific instrument to measure entrepreneurial intentions. Entrepreneurship Theory and Practice, 33(3), 593-617.

Liñán, F., Urbano, D., \& Guerrero, M. (2011). Regional variations in entrepreneurial cognitions: Start-up intentions of university students in Spain. Entrepreneurship and Regional Development, 23(3\&4), 187-215. doi: 10.1080/0898562090323392

Moriano, J. A. (2005). El perfil psicosocial del emprendedor : un estudio realizado en Castilla y León. Madrid: Consejo Económico y Social.

Mueller, S. L., \& Thomas, A. S. (2001). Culture and entrepreneurial potential: A nine country study of locus of control and innovativeness. Journal of Business Venturing, 16(1), 51-75.

Nunnally, J. C. (1978). Psychometric Theory. New York: McGraw-Hill.

Rauch, A., \& Frese, M. (2007). Let's put the person back into entrepreneurship research: A meta-analysis on the relationship between business owners' personality traits, business creation, and success. European Journal of Work and Organizational Psychology, 16(4), 353-385.

Reitan, B. (1997). Where do we learn that entrepreneurship is feasible, desirable and/or profitable? - A look at the processes leading to entrepreneurial potential. Paper presented at the ICSB World Conference(San Francisco, CA).

Robinson, P. B., Stimpson, D. V., Huefner, J., \& Hunt, H. K. (1991). An attitude approach to the prediction of entrepreneurship. Entrepreneurship Theory and Practice, 15(4), 1331.

Rotter, J. B. (1966). Generalized expectancies for internal versus external control of reinforcement. Psychological Monographs: General \& Applied, 80(1), 1-28.

Schmitt-Rodermund, E., \& Vondracek, F. W. (2002). Occupational dreams, choices and aspirations: Adolescents' entrepreneurial prospects and orientations. Journal of Adolescence, 25(1), 65-78.

Shapero, A., \& Sokol, L. (1982). Social dimensions of entrepreneurship. In C. A. Kent, D. L. Sexton \& K. H. Vesper (Eds.), Encyclopedia of entrepreneurship (pp. 72-90). Englewood Cliffs (NJ): Prentice Hall.

Thompson, E. R. (2009). Individual entrepreneurial intent: construct clarification and development of an internationally reliable metric. Entrepreneurship Theory and Practice, 33(3), 669-694. 
Tkachev, A., \& Kolvereid, L. (1999). Self-employment intentions among Russian students. Entrepreneurship and Regional Development, 11(3), 269-280.

van Gelderen, M., Brand, M., van Praag, M., Bodewes, W., Poutsma, E., \& van Gils, A. (2008). Explaining entrepreneurial intentions by means of the theory of planned behaviour. Career Development International, 13, 538-559. doi: 10.1108/13620430810901688

Vesalainen, J., \& Pihkala, T. (1999). Motivation structure and entrepreneurial intentions. In P. Reynolds, W. D. Bygrave, S. Manigart, C. Maston, G. D. Meyer, H. J. Sapienza \& K. G. Shaver (Eds.), Frontiers of entrepreneurship research (pp. 73-87). Babson Park, MA: Babson College.

Zhao, H., Siebert, S. E., \& Hills, G. E. (2005). The mediating role of self-efficacy in the development of entrepreneurial intentions. Journal of Applied Psychology, 90(6), 1265-1272. 
Table 1. Sample characteristics

\begin{tabular}{|c|c|c|c|c|c|c|c|}
\hline & Mean & Std. dev. & $\begin{array}{c}0 \\
(\%) \\
\end{array}$ & $\begin{array}{c}1 \\
(\%)\end{array}$ & $\begin{array}{c}2 \\
(\%) \\
\end{array}$ & $\begin{array}{c}3 \\
(\%) \\
\end{array}$ & $\begin{array}{c}4 \\
(\%) \\
\end{array}$ \\
\hline \multirow[t]{2}{*}{ Age } & 28.08 & 4.98 & & & & & \\
\hline & & & Female & Male & & & \\
\hline \multirow[t]{2}{*}{ Gender } & 0.43 & 0.49 & 57.5 & 42.5 & & & \\
\hline & & & No & Yes & & & \\
\hline Labor experience & 0.90 & 0.30 & 9.8 & 90.2 & & & \\
\hline $\begin{array}{l}\text { Self-employment } \\
\text { experience }\end{array}$ & 0.13 & 0.34 & 86.6 & 13.4 & & & \\
\hline Family role model & 0.62 & 0.49 & 37.9 & 62.1 & & & \\
\hline $\begin{array}{l}\text { Contact entrepreneurship } \\
\text { center }\end{array}$ & 0.19 & 0.39 & 80.8 & 19.2 & & & \\
\hline & & & Lower & $\begin{array}{l}\text { Lower- } \\
\text { middle }\end{array}$ & Middle & $\begin{array}{l}\text { Upper- } \\
\text { middle }\end{array}$ & Upper \\
\hline Socioeconomic level & 1.89 & 0.65 & 2.6 & 19.1 & 65.1 & 13.1 & 0.2 \\
\hline & & & $\begin{array}{c}\text { Private } \\
\text { sector } \\
\text { employe } \\
\text { e } \\
\end{array}$ & $\begin{array}{c}\text { Public } \\
\text { sector } \\
\text { employee }\end{array}$ & \begin{tabular}{|c|}
$\begin{array}{c}\text { Self- } \\
\text { employed }\end{array}$ \\
\end{tabular} & \begin{tabular}{|c|} 
Unemploy \\
ed
\end{tabular} & Other \\
\hline Occupational status & -- & -- & 40.8 & 16.3 & 7.1 & 28.2 & 7.5 \\
\hline
\end{tabular}


Table 2. Individual Loadings $(\lambda)$, Composite Reliabilities $\left(\rho_{c}\right)$, and AVE.

\begin{tabular}{lcccc}
\hline Construct & Indicators & $\lambda$ & $A V E$ & $\rho_{c}$ \\
\hline Attitude & $\mathrm{A} 1$ & .79 & .50 & .82 \\
& $\mathrm{~A} 2$ & .58 & & \\
& $\mathrm{~A} 3$ & .68 & & \\
& A4* & .50 & & \\
& $\mathrm{~A} 5$ & .68 & & \\
& $\mathrm{~A} 6$ & .68 & & .87 \\
& SN1 & .85 & .70 & \\
\hline Subjective Norm & SN2 & .88 & & \\
& SN3 & .76 & & \\
& ESE1 & .82 & .66 & \\
& ESE2 & .82 & & \\
& ESE3 & .80 & & \\
& ESE4 & .80 & & \\
& ESE5 & .77 & & \\
& ESE6 & .86 & & \\
\hline Entrepreneurial Self-Efficacy & I1 & .92 & .70 & \\
& I2 & .93 & & \\
& I3 & .94 & & \\
& I4 & .91 & & \\
\hline
\end{tabular}

Note. * Item removed from the model due to the low loading on the attitude scale 
Table 3. Means, standard deviations, correlations, and discriminant validity

\begin{tabular}{lcccccc}
\hline Constructs & Mean & $S D$ & 1 & 2 & 3 & 5 \\
\hline 1. Attitude & 2.90 & 0.90 & .70 & & & \\
2. Subjective Norm & 2.83 & 1.15 & $.36^{* *}$ & .83 & & \\
3. Entrepreneurial Self-efficacy & 3.85 & 1.17 & $.54^{* *}$ & $.34^{* *}$ & .81 & \\
5. Entrepreneurial Intention & 2.92 & 1.65 & $.50^{* *}$ & $.35^{* *}$ & $.56^{* *}$ & .83 \\
\hline
\end{tabular}

Notes. Diagonal elements are the square root of AVE between the constructs and their indicators. Off-diagonal elements are correlations: $* p<.05$; $* * p<.01$. For discriminant validity, diagonal elements should be greater than off-diagonals elements in the same row and column; 
Figure 1. Theoretical model

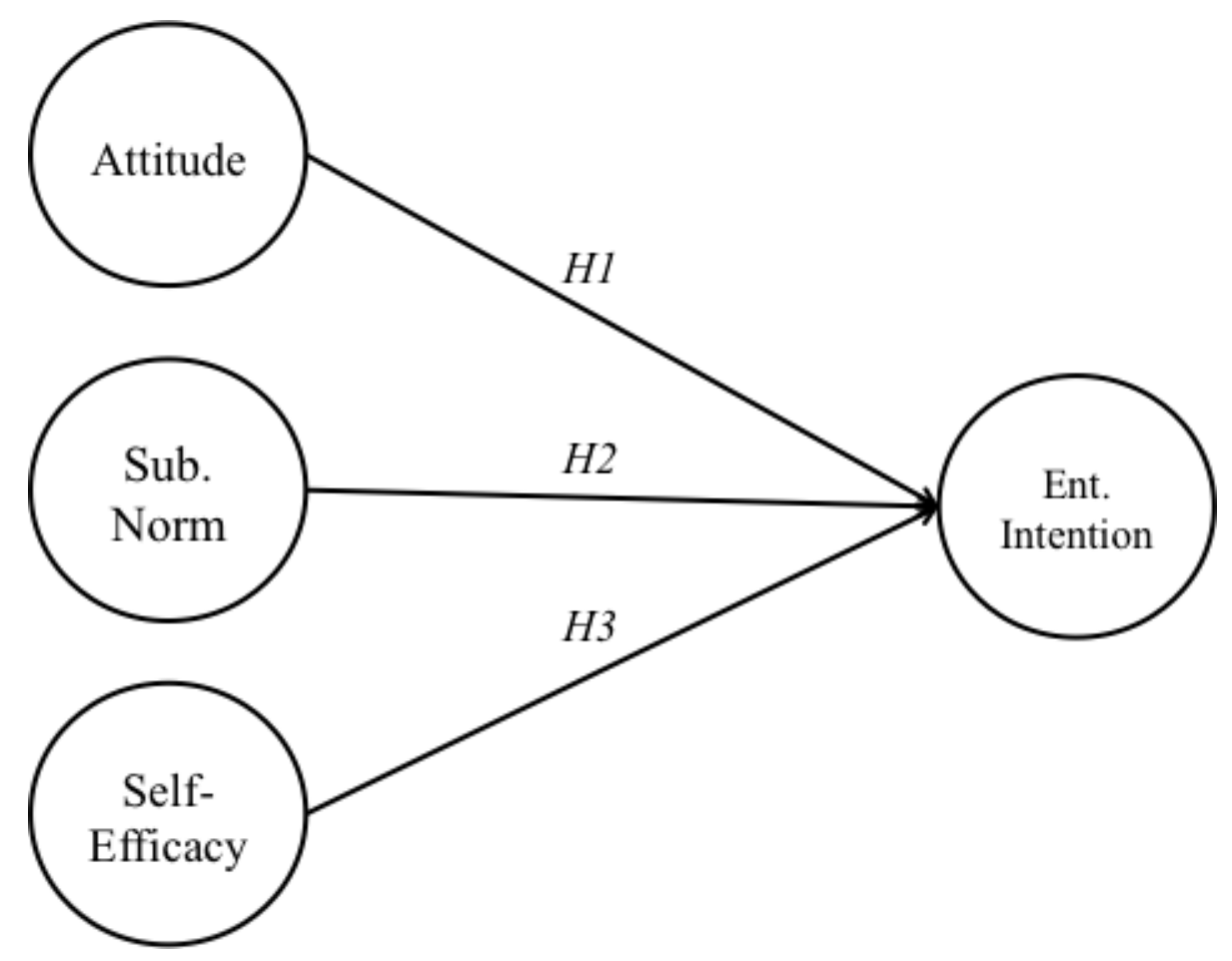

Figure 2. Structural model

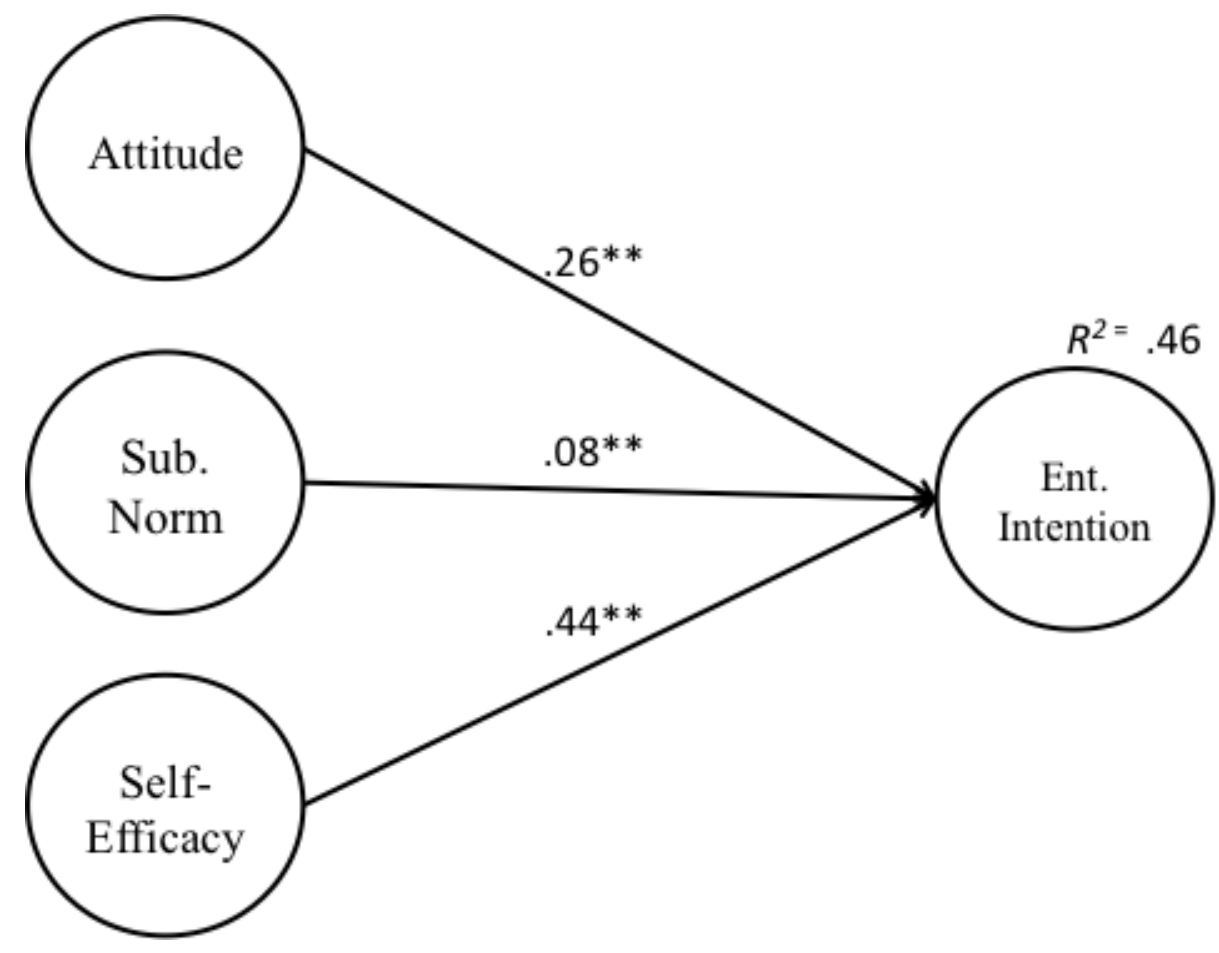

